\title{
APPLICABILITY OF MOYERS' PROBABILITY TABLE IN THE POPULATION OF THE NORTHEAST OF BRAZIL
}

\author{
APLICABILIDADE DA TABELA DE PROBABILIDADE DE MOYERS NA \\ POPULAÇÃO DO NORDESTE DO BRASIL
}

\author{
Matheus Melo PITHON ${ }^{1}$ Rogério LACERDA-SANTOS ${ }^{2}$; Jean Thiago Silva ARAÚJO³; \\ Raildo da Silva COQUEIRO ${ }^{4}$ \\ 1. Professor, Department of Orthodontics, State University of Sudoeste da Bahia, Jéquie, Bahia, Brazil. matheuspithon@gmail.com; 2. \\ Professor, Department of Orthodontics, Federal University of Campina Grande, Patos, Paraíba, Brazil. lacerdaorto@ hotmail.com; 3. \\ Student of Dentistry, Department of Orthodontics, State University of Sudoeste da Bahia, Jéquie, Bahia, Brazil; 4. Professor, \\ Department of Epidemiology, Center for Studies in Aging, State University of Sudoeste da Bahia, Jéquie, Bahia, Brazil.
}

\begin{abstract}
This study aimed to evaluate the applicability and reliability of Moyers' probability tables in a sample population of youngsters in the Northeast of Brazil. A total of 200 plaster casts of the mandibular arch were evaluated, whom 99 were men and 101 females, aged 15-19 years. For this purpose a digital pachymeter was used to measure the mesiodistal widths of the tooth crowns. The values of the mesiodistal diameters obtained were submitted to statistical analysis by simple linear regression. Only the canine/premolar segment presented significant difference $(\mathrm{p}<.001)$ between the mesiodistal diameters of the individuals of the male and female genders, and the male gender presented broader teeth. The regression equations for the mandibular arch for men, $\mathrm{Y}=13.42+0.37(\mathrm{X})$ and women, $\mathrm{Y}=8.79+$ $0.55(\mathrm{X})$, demonstrated that Moyers' tables with 75 percentage levels, tended to underestimate the real sum of the mandibular permanent canine and premolar of individuals of the male and female gender, however, without statistical difference ( $p>.05)$. It could be concluded that there was sexual dimorphism in the size of the teeth for the canine/premolar segment, with men presenting broader teeth. Moyers' probability tables were shown to be reliable for application in white individuals in the Northeast of Brazil.
\end{abstract}

KEYWORDS: Orthodontics. Tooth. Mixed dentition. Analysis.

\section{INTRODUCTION}

The mixed dentition stage is extremely dynamic and subject to alterations during its normal development, such as early loss or primary teeth and/or loss of dental structure due to caries (LEECHAN et al.,1998).

The methods for the analysis of mixed dentition are valuable auxiliary means in preventive and interceptive orthodontic treatments, which assess whether or not there will be sufficient space in the dental arch to accommodate the permanent teeth, from the primate spaces, diastemas, Leeway Space, space generated by growth of the arches and by changes in the inclination of the permanent teeth (PAULA et al., 1995; LEE-CHAN et al.,1998). Nance (1947) described the Leeway Space as being $3.4 \mathrm{~mm}$ in the mandible and $1.8 \mathrm{~mm}$ in the maxilla. The arch length is generally diminished during the transition from mixed to permanent dentition, particularly the mandibular arch (NANCE, 1947; GIANELLY, 2002). Since conserving or recovering space is critical in the mandible, the analysis of arch length discrepancy is indicated (PAULA et al., 1995).

Moyers (1988) proposed a method based on predictive tables, used to estimate the mesiodistal width of the unerupted permanent canines and premolars, and this became an important, widely used procedure (PHILIP et al., 2010) in patients in the mixed dentition stage (TANAKA; JOHNSTON, 1974; PAULA et al., 1995; GIANELLY et al., 2002).

However, Moyers (1988) used a population sample of North American individuals, and it has been questioned whether these values found by Moyers (1988) are reliable when applied to a different racial group or populations of different ethnic origin (NANCE, 1947; VAN DER MERWE et al., 1991; PAULA et al., 1995; URSUS; WILTSHIRE, 1997; NOURALLAH et al., 2002; SAYIN; TURKKAHRAMAN, 2004).

Therefore, the aim of this study was to evaluate the applicability and reliability of Moyers' probability tables in a sample population of youngsters in the Northeast of Brazil.

\section{MATERIAL AND METHODS}

A total of 200 plaster casts of the mandibular arch were used in this study, of which 99 were from white individuals of the male and 101 of white individuals of the female gender, in the age-range from 15 to 19 years, from a young 
population in the Brazilian Northeast. The orthodontic study models were obtained with the use of high quality stone plaster (Stone plaster type III; Vigodent Indústria e Comércio Ltda, Rio de Janeiro, Brazil). This study was previously approved by the ethics committee on Human Research (CEP/N.463-175/2011, CAAE0154.0.454.00011).

The inclusion criteria adopted for sample selection were as follows: white individuals, completely erupted mandibular permanent central and lateral incisors, canines and premolars; absence of loss of dental structure in the interproximal regions as a result of caries lesions, fractures, congenital defects or interproximal wear; the dental impressions and the plaster casts should be of high quality and free of distortions; the individuals could not present a previous history of orthodontic treatment or severe crowding which would compromise mesiodistal measurement of the teeth (VAN DER MERWE et al., 1991; URSUS; WILTSHIRE, 1997; LEGOVIC et al., 2003; MARINELLI et al., 2005; MELGAÇO et al., 2006).
Was considered as exclusion criterion from sample any factor that was not in accordance with the inclusion criteria, as well as other ethnic groups.

A digital electronic pachymeter $(0-150 \mathrm{~mm}$, 500-682, Mitutoyo Sul Americana LTDA, Suzano, São Paulo, Brazil) with a resolution of $0.01 \mathrm{~mm}$ and accuracy of $\pm 0.02 \mathrm{~mm}$ was used to measure the largest mesiodistal crown diameters (Figure 1), parallel to the occlusal surface and perpendicular to the long axis of the tooth (VERZI et al., 2002; LEGOVIC et al., 2003; MELGAÇO et al., 2006). For better adjustment of the interdental spaces, the pachymeter points of measurement were slightly narrowed (URSUS; WILTSHIRE, 1997; LEGOVIC et al., 2003).

To determine the reliability of the measurements, the same examiner performed the measurements of the mesiodistal diameters from the mandibular second premolar to the mandibular second premolar on the opposite side of 30 randomly selected casts ( 15 of the male and 15 of the female gender), twice in an interval of 10 days.

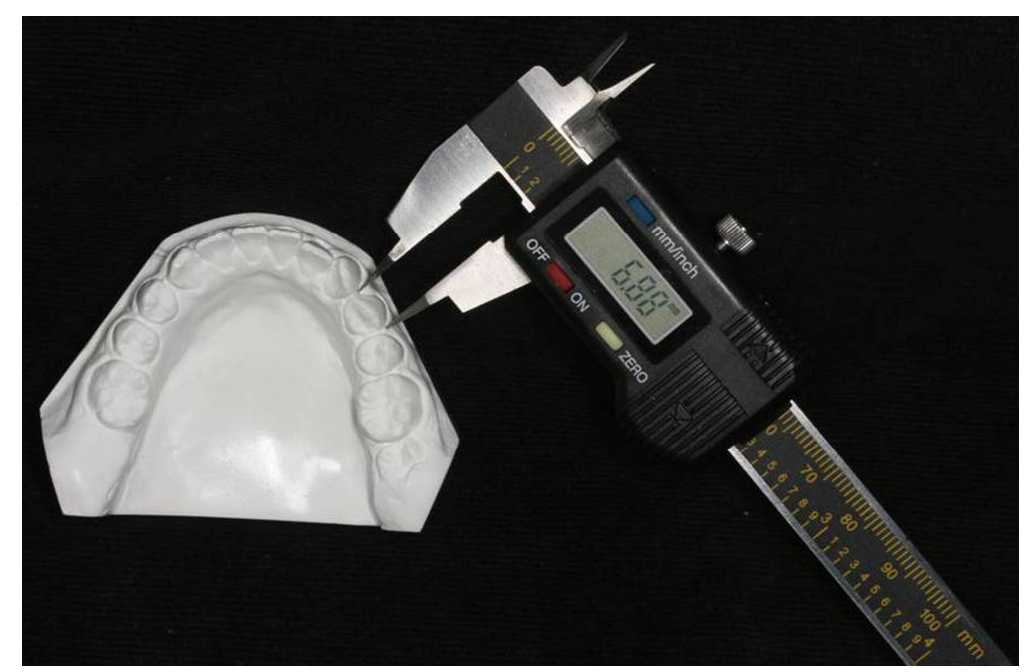

Figure 1: Measurement of the mesiodistal diameter of the tooth crowns using a digital pachymeter.

For evaluation of Moyers (1988) method the probability graphs of 75 percentage levels were used to estimate the mandibular permanent canine and premolar widths, from the sum of the 4 mandibular incisors. The evaluation was made in the mandibular arch only, because conserving or recovering space is critical in the mandible (PAULA; ALMEIDA, 1987; MELGAÇO et al., 2006).

The sample size was previously determined. The descriptive statistics used in this study included calculation of the mean, standard deviation and minimum and maximum values. The Student's- $t$ test for independent samples was performed to compare the mesiodistal diameter of the teeth between the genders. The Intraclass Correlation Coefficient (ICC) was used to determine the consistency of measurement.

To develop new regression equations for the studied population, the simple linear regression analysis was used. The correlation coefficients (r), coefficients of determination $\left(r^{2}\right)$ and standard error of estimate were calculated separately for the male and female genders. The predicted values were compared with the actual values measured of the 
participants by means of the Student's- $t$ test for paired samples. The level of significance adopted was $5 \%(\alpha=.05)$. The data were tabulated and analyzed in the statistical program BioEstat (version 5.0, Belém-PA, Brazil).

\section{RESULTS}

The mesiodistal diameter of the teeth evaluated presented statistical difference between the male and female genders only for the canine/premolar segment $(\mathrm{p}=.001)$. The male gender presented the largest mesiodistal diameters irrespective of the tooth evaluated (Table 1). There were no differences between the measurements of the right and left sides, irrespective of gender $(\mathrm{p}<.05)$.

Correlation and coefficients of determination were established (Table 2) and a standard error of estimate lower than $0.95 \mathrm{~mm}$ per segment was verified, establishing reliability for comparison with other studies.

Table 1. Descriptive statistics for the mesiodistal diameter of the two groups of teeth.

\begin{tabular}{llccc}
\hline Group of teeth & Gender & Min-max $(\mathbf{m m})$ & Mean \pm SD $(\mathbf{m m})$ & p-value \\
\hline lower Incisors & male & $19,87-27,76$ & $23,13 \pm 1,57$ & 0,053 \\
& female & $18,51-26,58$ & $22,73 \pm 1,32$ & \\
Segment canine / premolar & male & $19,34-25,40$ & $22,10 \pm 1,10$ & $<0,001$ \\
& female & $19,17-24,71$ & $21,30 \pm 1,18$ & \\
\hline
\end{tabular}

Min, minimum, max, maximum, SD, standard deviation. Student's t test $(\mathrm{p}<.01)$ for comparison between genders.

Table 2. Regression parameters for prediction of the mesiodistal diameter of the mandibular canine/premolar segment.

\begin{tabular}{llllll}
\hline \multicolumn{5}{c}{ Constants } \\
\hline Gender & $\mathrm{r}$ & $\mathrm{A}$ & $\mathrm{B}$ & $\mathrm{r}_{\text {adjusted }}$ & $\mathrm{SEE}(\mathrm{mm})$ \\
Male & 0,53 & 13,42 & 0,37 & 0,28 & 0,94 \\
Female & 0,61 & 8,78 & 0,55 & 0,37 & 0,94 \\
\hline r, correlation; & A and B, regression constant; r radjusted, coefficient of determination; SEE (mm), standard error of \\
estimate. &
\end{tabular}

The prediction equation for the mesiodistal diameter of the canine/premolar segment found in this study were compared with those of other authors, with the predictive equation for the male gender being: $13.42+0.37(\mathrm{x})$, and was significantly higher when compared with the female gender: 8.79 $+0.55(\mathrm{x})$ and both demonstrated higher values compared with those of other population studies (Table 3).

Table 3. Predictive equations of various studies.

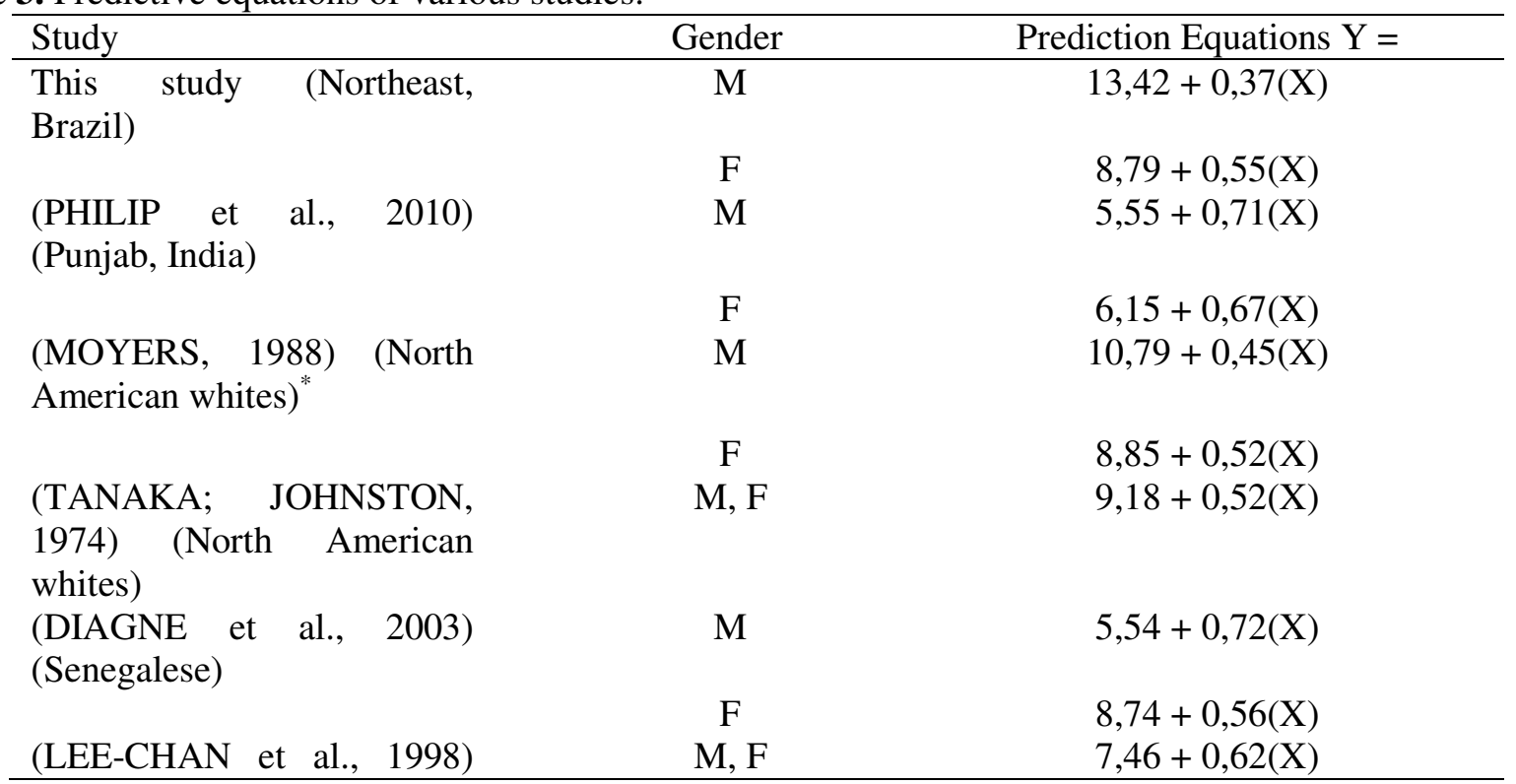




\begin{tabular}{|c|c|c|}
\hline $\begin{array}{l}\text { (Asian Americans) } \\
\text { (JAROONTHAM; } \\
\text { GODFREY, 2000) (Thai) }\end{array}$ & $\mathrm{M}$ & $11,92+0,43(X)$ \\
\hline & $\mathrm{F}$ & $9,49+0,53(\mathrm{X})$ \\
\hline $\begin{array}{l}\text { (ARSLAN et al., 2009) } \\
\text { (Turkish) }\end{array}$ & $\mathrm{M}$ & $\begin{array}{l}9,54+0,50(X) \\
9,14+0,50(X)\end{array}$ \\
\hline
\end{tabular}

Y, mesiodistal diameter of lower canine/premolar segment; X, mesiodistal diameter of the four lower incisors; M, male; F, female. * Regression equations derived of Moyers tables in the 50th percentile.

For the male and female genders, considering the 75 th percentile level, Moyers tends to underestimate the real sum of the mandibular permanent canines and premolars by $0.12 \pm 0.93 \mathrm{~mm}$ and $0.01 \pm 0.93 \mathrm{~mm}$, respectively (Table 4 and 5 ).
However, this difference was not statistically significant $(\mathrm{p}=.18)$ and $(\mathrm{p}=.90)$, with the application of the predictive equations of both genders in this study (Table 4 and 5), indicating the reliability of the use of Moyers' Tables for the evaluated population.

Table 4. Comparison of the actual and predicted values.

\begin{tabular}{|c|c|c|c|c|c|c|c|}
\hline \multirow[t]{2}{*}{ Gender } & \multicolumn{2}{|c|}{$\begin{array}{c}\text { predicted } \\
\text { values }(\mathbf{m m})\end{array}$} & \multicolumn{2}{|c|}{$\begin{array}{c}\text { Current } \\
\text { values }(\mathbf{m m})\end{array}$} & \multicolumn{2}{|c|}{$\begin{array}{l}\text { Difference } \\
(\mathbf{m m})\end{array}$} & \multirow[t]{2}{*}{ P-value } \\
\hline & Mean & SD & Mean & SD & Mean & SD & \\
\hline Male & 21,98 & 0,58 & 22,10 & 1,10 & $-0,12$ & 0,93 & 0,189 \\
\hline Female & 21,29 & 0,73 & 21,30 & 1,18 & $-0,01$ & 0,93 & 0,906 \\
\hline
\end{tabular}

Table 5. Predictive table calculated of the respective regression equations for the studied population, based on the sum of the four mandibular permanent incisors.

\begin{tabular}{lcc}
\hline$\sum$ IPM & Male & Female \\
19,0 & 21,45 & 19,24 \\
19,5 & 21,64 & 19,52 \\
20,0 & 21,82 & 19,79 \\
20,5 & 22,01 & 20,07 \\
21,0 & 22,19 & 20,34 \\
21,5 & 22,38 & 20,62 \\
22,0 & 22,56 & 20,89 \\
22,5 & 22,75 & 21,17 \\
23,0 & 22,93 & 21,44 \\
23,5 & 23,12 & 21,72 \\
24,0 & 23,30 & 21,99 \\
24,5 & 23,49 & 22,27 \\
25,0 & 23,67 & 22,54 \\
25,5 & 23,86 & 22,82 \\
\hline
\end{tabular}

$\Sigma$ IPM, sum of the lower permanent incisors.

\section{DISCUSSION}

Dental characteristics differ among populations of different racial or ethnic origin (VAN DER MERWE et al., 1991; PAULA et al., 1995; URSUS; WILTSHIRE, 1997; VERZI et al., 2002; SAYIN; TURKKAHRAMAN, 2004; MARINELLI et al., 2005). One of the methods most used in mixed dentition to predict with widths of unerupted permanent teeth was developed by Moyers (1988) in a North American population (MOYERS, 1988).

However, researches with the purpose of confirming the applicability and efficacy of this method in different populations are necessary, and this was the reason for this study, as there is a scarcity of studies with this purpose, and this information has become important in determining the treatment plan in the studied populations. 
To assess the mesiodistal diameter of the teeth, a digital compass was used in order to obtain exact measurements (WARREN; BISHARA, 2001; KESKI-NISULA et al., 2003). The ICC (0.99) value shown in this study is in agreement with values found by other authors (STALEY; HOAG, 1978; SAYIN; TURKKAHRAMAN, 2004; MELGAÇO et al., 2006), which demonstrates the reliability of the measurements. The predictive method used in this study was based on the mean of the tooth sizes on the two sides.

The findings of this study showed that significant differences were found between the tooth widths for the canine/premolar segment of both genders, and this is in agreement with various authors (MOYERS, 1988; VAN DER MERWE et al., 1991; VERZI et al., 2002; DIAGNE et al., 2003; LEGOVIC et al., 2003). On the other hand, other researches did not consider differences between genders (TANAKA; JOHNSTON, 1974; VAN DER MERWE et al., 1991; AL-KHADRA, 1993).

When considering the Moyers probability table, which ranges from 5 to $95 \%$, the $75 \%$ percentile is the one most used in the studies, and is justified by Moyers (1988) as being a percentile with a tendency to overestimate the values, with the purpose of protecting the patient against eventual tooth crowding. In this study, when the samples of both genders were evaluated in relation to Moyers' tables at the 75th percentile levels, they tended to underestimate the sum of the permanent canines and premolars. These results have corroborated those of other authors (VAN DER MERWE et al., 1991; URSUS; WILTSHIRE, 1997; MELGAÇO et al., 2006), but are not in agreement with other studies that found that the percentage level of 75 tended to overestimate the measurements (PAULA; ALMEIDA, 1987; AL-KHADRA, 1993; VERZI et al., 2002; DIAGNE et al., 2003). Whereas, some authors found no difference when the Moyers method with the 75th percentile was used (PAULA, et al., 1995).

The mesiodistal diameter of the canine/premolar segment presented a significant difference $(\mathrm{P}<.01)$ between the genders. This sexual dimorphism observed with regard to the diameter of the teeth corroborates the findings of other studies (MOYERS, 1988; PAULA et al., 1995; JAROONTHAM; GODFREY, 2000; DIAGNE et al., 2003). The significant differences between the genders, observed in the mesiodistal diameter of the teeth is of a relevant nature, which determines the development of individualized interceptive treatments in mixed dentition (PHILIP et al., 2010).
The variability of the results found when the Moyers method was applied in Brazilian individuals, may be connected with the differences between the sample sizes and ethnic origins. Moreover, in Brazil there are various different characteristics in the population with the same ethnic origin due to miscegenation (MELGAÇO et al., 2006).

Based on the correlation coefficients obtained (Table 2) a similarity could be verified between the findings of this study and those of other authors: (0.82-0.72) (PAULA et al., 1995), (0.740.69) (JAROONTHAM; GODFREY, 2000), (0.730.63) (TANAKA; JOHNSTON, 1974), (0.68-0.67) (PHILIP et al., 2010), (0.58-0.65) (ARSLAN et al., 2009), and (0.66) (LEE-CHAN et al., 1998) for the male and female genders respectively. It is suggested that these relatively consistent correlations $(0.60-0.70)$ between the combined mesiodistal diameters of the mandibular permanent incisors may signify that $60 \%$ to $70 \%$ of the genes that determine tooth size are shared between the mandibular incisors, canines (CHUNG et al., 2011) and premolars (TANAKA; JOHNSTON, 1974). This common genetic code provides theoretical justification for the estimate of mandibular canine and premolar widths, in spite of these teeth belonging to different morphological classes (PHILIP et al., 2010).

The multiple regression analysis also indicated that the combined mesiodistal diameters of the mandibular permanent incisors is the best non radiographic predictive variable for estimating the mesiodistal diameter of unerupted canines and premolars in both arches (PHILIP et al., 2010). The use of the mandibular permanent incisors as a predictive variable has several advantages: they erupt at the onset of mixed dentition, may easily be measured, show little variability in size, and are directly related to spaces and the management of the problems (MOYERS, 1988; BHERWANI; FIDA, 2011; RAKESH; JALILI, 2011).

The coefficients of determination $\left(\mathrm{r}^{2}\right)$, indicate the predictive accuracy of the equations, which ranged between 0.28 and 0.37 for the canine/premolar segment (Table 2). This means that $28 \%$ to $37 \%$ of the total variance in canine/premolar widths is accounted for by knowing the combined widths of the mandibular incisors. The error involved in the use of the regression equation is indicated by the standard error of estimate (SEE); the lower the error, the better the prediction of the equation. In this study the SEE value was $0.94 \mathrm{~mm}$ (Table 2), for both genders, and are similar to the values related by Moyers (1988), Tanaka and 
Johnston (1974), and lower than the values related by other authors (JAROONTHAM; GODFREY, 2000; DIAGNE et al., 2003; ARSLAN et al., 2009; PHILIP et al., 2010).

From the regression constant (Table 2), the predictive equations for the male and female genders $(\mathrm{Y}=13.42+0.37(\mathrm{X}) ; \mathrm{Y}=8.79+0.55(\mathrm{X})$ respectively, were determined, where $y$ is the sum of the unerupted permanent canine/premolar segment on each side and $\mathrm{x}$ is the sum of the diameters of the four mandibular permanent incisors. These equations confirm the result found in Table 1, in which the individuals of the male gender presented broader teeth for the canine/premolar segment in relation to the female gender. These findings are similar to those shown in other studies (TANAKA; JOHNSTON, 1974; MOYERS, 1988; VAN DER MERWE et al., 1991; AL-KHADRA, 1993; DIAGNE et al., 2003), indicating that there is a correlation between the four mandibular permanent incisors and the effective widths of the maxillary permanent canines and premolars in white Brazilian individuals.

From the predictive equations used to calculate the differences between the predicted distances and the actual measurements (Table 4), the absence of statistical differences may be verified, which indicates the reliability of the predictions (BHERWANI; FIDA, 2011). The predicted values (Table 5) calculated from the sum of the mesiodistal diameters of the mandibular permanent incisors showed no statistically significant differences between the predicted and actual values (TANAKA;
JOHNSTON, 1974; DIAGNE et al., 2003; MARTINELLI et al., 2005).

In spite of the increase in the use of computerized tomography, which easily identifies the size of teeth without the occurrence of measurement errors, this is still not widely used and not very accessible when one thinks in terms of public health. In addition it emits radiation that may be connected with the occurrence or potentiation of health problems (NGUYEN et al., 2011).

The use of the Moyers (1998) method is based on the principle of a minimum systematic error, safe use by both the beginner and the specialist, fast application without the use of periapical radiographs and the possibility of direct application in the oral cavity. Based on this studied population, the Moyers Tables may be considered reliable for predicting the mesiodistal diameters of the unerupted canines and premolars, providing a fast diagnosis with respect to the lack or excess of spaces, allowing orthodontic treatment to be performed as early as possible (URZAL et al., 2013; SHAH et al., 2013).

\section{CONCLUSIONS}

There is sexual dimorphism in the size of the teeth for the canine/premolar segment, with men presenting broader teeth than women.

Moyers' probability tables were shown to be reliable for application in white individuals in the Northeast of Brazil.

RESUMO: Este estudo objetivou avaliar a aplicabilidade e a confiabilidade das tabelas de Moyers em uma amostra populacional de jovens do Nordeste brasileiro. Um total de 200 modelos de gesso da arcada inferior foram avaliados, sendo 99 indivíduos do gênero masculino e 101 do gênero feminino, na faixa etária de 15 a 19 anos. Para tal foi utilizado paquímetro digital para realizar a medição das larguras mésio-distais das coroas dos dentes. Os valores dos diâmetros mésio-distais obtidos foram submetidos à análise estatística de regressão linear simples. Apenas o segmento canino/pré-molares apresentou diferença significativa $(\mathrm{p}<0.001)$ entre os diâmetros mésio-distais dos indivíduos do gênero masculino e feminino, sendo que o gênero masculino apresentou dentes mais largos. As equações de regressão para o arco inferior para homens, $\mathrm{Y}=13,42+0,37(\mathrm{X})$ e Mulheres, $\mathrm{Y}=8,79+0,55(\mathrm{X})$, demonstraram que as Tabelas de Moyers com 75 níveis percentuais, tenderam a subestimar a soma real do canino inferior permanente e pré-molares para indivíduos do gênero masculino e feminino, no entanto, sem diferença estatística ( $\mathrm{p}>0.05)$. Pôde-se concluir que há dimorfismo sexual, no tamanho dos dentes para o segmento canino/pré-molares, com os homens apresentando dentes mais largos. As tabelas de probabilidade de Moyers mostraram ser confiáveis para ser aplicadas em indivíduos brancos do nordeste brasileiro.

PALAVRAS CHA VES: Ortodontia. Dentes. Dentição mista. Análise.

\section{REFERENCES}

AL-KHADRA, B. H. Prediction of the size of unerupted canines and premolars in a Saudi Arab population. Am J Orthod Dentofacial Orthop. St. Louis, v. 104, n. 4, p. 369-372, 1993. 
ARSLAN, S. G.; DILDES, N.; KAMA, J. D.; GENC, C. Mixed-dentition analysis in a Turkish population. World J Orthod. Hanover Park, v. 10, n. 2, p. 135-140, 2009.

BHERWANI, A. K. B.; FIDA, M. Development of a prediction equation for the mixed dentition in a Pakistani sample. Am J Orthod Dentofacial Orthop. St. Louis, v. 140, n. 5, p. 626-63, 2011.

CHUNG, D. D.; WEISBERG, M.; PAGALA, M. Incidence and effects of genetic factors on canine impaction in an isolated Jewish population. Am J Orthod Dentofacial Orthop. St. Louis, v. 139, n. 4, p. e331-e335, 2011.

DIAGNE, F.; DIOP-BA, K.; NGOM, P. I.; MBOW, K. Mixed dentition analysis in a Senegalese population: elaboration of prediction tables. Am J Orthod Dentofacial Orthop. St. Louis, v. 124, n. 2, p. 178-183, 2003.

GIANELLY, A. A. Treatment of crowding in the mixed dentition. Am J Orthod Dentofacial Orthop. St. Louis, v. 121, n. 6, p. 569-571, 2002.

JAROONTHAM, J.; GODFREY, K. Mixed dentition space analysis in a Thai population. Eur J Orthod. Oxford, v. 22, n. 2, p. 127-134, 2000.

KESKI-NISULA, K.; LEHTO, R.; LUSA, V.; KESKI-NISULA, L.; VARRELA, J. Occurrence of malocclusion and need of orthodontic treatment in early mixed dentition. Am J Orthod Dentofacial Orthop. St. Louis, v. 124, n. 6, p. 631-638, 2003.

LEE-CHAN, S.; JACOBSON, B. N.; CHWA, K. H.; JACOBSON, R. S. Mixed dentition analysis for AsianAmericans. Am J Orthod Dentofacial Orthop. St. Louis, v. 113, n. 3, p. 293-299, 1998.

LEGOVIC, M.; NOVOSEL, A.; LEGOVIC, A. Regression equations for determining mesiodistal crown diameters of canines and premolars. Angle Orthod. Appleton, v. 73, n. 3, p. 314-318, 2003.

MARINELLI, A.; ALARASHI, M.; DEFRAIA, E.; ANTONINI, A.; TOLLARO, I. Tooth wear in the mixed dentition: a comparative study between children born in the 1950s and the 1990s. Angle Orthod. Appleton, v. 75, n. 3, p. 318-321, 2005.

MARTINELLI, F. L.; LIMA, E. M.; ROCHA, R.; ARAUÚJO, M. S. T. Prediction of lower permanent canine and premolars width by correlation methods. Angle Orthod. Appleton, v. 75, n. 5, p. 236-240, 2005.

MELGAÇO, C. A.; ARAÚJO, M. T.; RUELLAS, A. C. O. Applicability of Three Tooth Size Prediction Methods for White Brazilians. Angle Orthod. Appleton, v. 76, n. 4, p. 644-49, 2006.

MOYERS, R. E. Handbook of Orthodontics. 4 ed. Chicago: Yearbook Med Publ Inc, 1988. 577 p.

NANCE, H. N. The limitations of orthodontic treatment I- mixed dentition diagnosis and treatment. Am J Orthod Oral Surg. St. Louis, v. 33, n. 4, p. 177-223, 1947.

NGUYEN, E.; BOYCHUK, D.; ORELLANA, M. Accuracy of cone-beam computed tomography in predicting the diameter of unerupted teeth. Am J Orthod Dentofacial Orthop. St. Louis, v. 140, n. 2, p. e59-66, 2011.

NOURALLAH, A. W.; GESCH, D.; KHORDAJI, M. N.; SPLIETH, C. New regression equations for predicting the size of unerupted canines and premolars in a contemporary population. Angle Orthod. Appleton, v. 72 , n. 3, p. 216-221, 2002.

PAULA, S.; ALMEIDA, M. A. Comparative analysis between methods prediction of the mesio-distal diameter of canines and pre-molars non-erupted. R Bras Odontol. Rio de Janeiro, v. XLIV, n. 5, p. 6-23, 1987. 
PAULA, S.; ALMEIDA, M. A. O.; LEE, P. C. F. Prediction of mesiodistal diameter of unerupted lower canines and premolars using 45 degrees cephalometric radiography. Am J Orthod Dentofacial Orthop. St. Louis, v. 107, n. 3, p. 309-314, 1995.

PHILIP, N. I.; PRABHAKAR, M.; ARORA, D.; CHOPRA, S. Applicability of the Moyers mixed dentition probability tables and new prediction aids for a contemporary population in India. Am J Orthod Dentofacial Orthop. St. Louis, v. 138, n. 3, p. 339-345, 2010.

RAKESH, T.; JALILI, V. P. Prediction of size of unerupted permanent canines \& premolars in subjects of madhya pradesh. J Pierre Fauch Acad. Madhya Pradesh, v. 25, n. 2, p. 93-97, 2011.

SAYIN, M. O.; TURKKAHRAMAN, H. Factors contributing to mandibular anterior crowding in the early mixed dentition. Angle Orthod. Appleton, 2004; v. 74, n. 6, p. 754-758, 2004.

SHAH, S.; BHASKAR, V.; VENKATARAGHVAN, K.; CHOUDHARY, P.; MAHADEVAN, G.; TRIVEDI, $\mathrm{K}$. Applicability of regression equation using widths of mandibular permanent first molars and incisors as a predictor of widths of mandibular canines and premolars in contemporary Indian population. J Indian Soc Pedod Prev Dent. New Delhi, v. 31, n. 3, p. 135-40, 2013.

STALEY, R. N.; HOAG, J. F. Prediction of the mesiodistal widths of maxillary permanent canines and premolars. Am J Orthod. St. Louis, v. 73, n. 2, p. 169-177, 1978.

TANAKA, M. M.; JOHNSTON, L. E. The prediction of the size of unerupted canines and premolars in a contemporary orthodontic population. J Am Dent Assoc. Chicago, v. 88, n. 4, p. 798-801, 1974.

URSUS, R. S.; WILTSHIRE, W. A. Orthodontic probability tables for black patients of African descent: mixed dentition analysis. Am J Orthod Dentofacial Orthop. St. Louis, v. 112, n. 5, p. 545-551, 1997.

URZAL, V.; BRAGA, A. C.; FERREIRA, A. P. The prevalence of anterior open bite in Portuguese children during deciduous and mixed dentition - Correlations for a prevention strategy. Int Orthod. Paris, v. 11, n. 1, p. 93-103, 2013. http://dx.doi.org/10.1016/j.ortho.2012.12.002

VAN DER MERWE, S. W.; ROSSOUW, P.; VAN WYK KOTZE, T. J.; TRUTERO, H. An adaptation of the Moyers mixed dentition space analysis for a Western Cape Caucasian population. J Dent Assoc S Afr. Cidade do Cabo, v. 46, n. 9, p. 475-479, 1991.

VERZI, P.; LEONARDI, M.; PALERMO, F. Analisi dello spazio médio delle arcate dentarie in un campione di soggetti della Sicilia orientle. Minerva Stomatol. Roma, v. 51, n. 7-8, p. 327-339, 2002.

WARREN, J. J.; BISHARA, S. E. Comparison of dental arch measurements in the primary dentition between contemporary and historic samples. Am J Orthod Dentofacial Orthop. St. Louis, v. 119, n. 3, p. 211-215, 2001. 